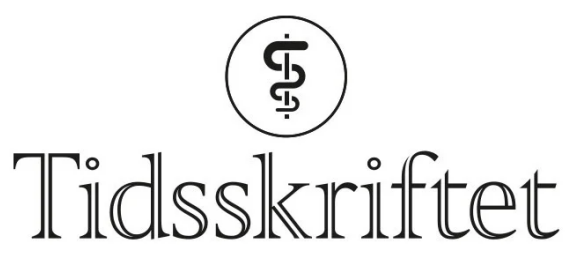

DEN NORSKE LEGEFORENING

\title{
Sjeflege eller sjefslege?
}

SPRÅKSPALTEN

\section{ERLEND HEM}

Erlend Hem (f. 1970) er dr.med. og assisterende redaktør i Tidsskriftet.

Email: erlend.hem@medisin.uio.no

Tidsskriftet

\section{Heter det sjeflege eller sjefslege? Svar: Det kan hete begge} deler, men ordene betegner ulike stillinger. Begge stillingskategorier er sjeldne i norsk medisin.

«Sjefsleger sier opp i protest», var hovedoppslaget på Dagsavisens førsteside nylig (fig 1). Legene hadde fătt nok av gigantfusjonen i Oslo. «Ti sjefsleger har sagt opp jobben i protest mot flyttekaos og kuttkrav fra det nye gigantsykehuset i Oslo,» sto det (1). Tidligere seksjonsoverlege ved Barnesenteret, Marit Hellebostad, uttalte at hun ikke var i stand til å gjøre en god jobb og mistet fullstendig kontrollen. Mange har forlatt den synkende skuta, sa hun. 


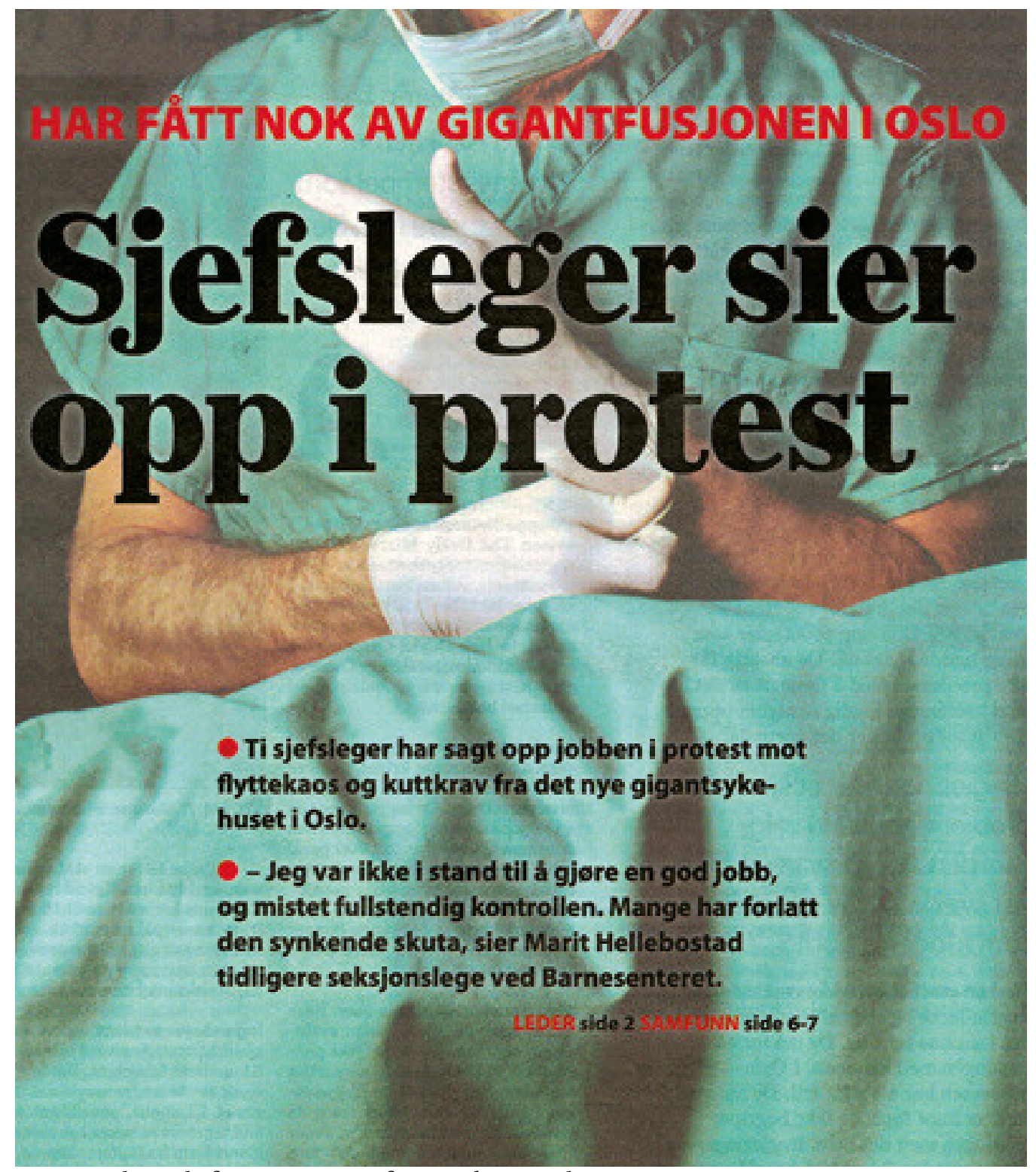

Figur 1 Faksimile fra Dagsavisens førsteside 2. april 2012

Det var ordet sjefsleger som fikk det til å rykke i norsklærerisjiasnerven, som Finn-Erik Vinje sier det. Når man setter sammen to substantiver til ett ord, kan man av og til trenge en bindebokstav. I ordet "visdomstann» er det -s- som brukes til å binde sammen visdom + tann, og kalles gjerne fuge-s eller binde-s (2 2 ). Ofte kan vi høre om det er behov for en slik bindebokstav: dødsattest, sykdomsutvikling, søknadsfrist, taushetsplikt. Vi er ikke i tvil om at det er behov for en -s-i disse eksemplene. Men i andre tilfeller er det vanskeligere (ramme 1) (2). Det er ikke like klart at det skal hete korsryggssmerter og trekarssykdom.

\section{Ramme 1}

\section{Noen problemord med og uten fuge-s}

Med fuge-s

- Fellesskap (ikke felleskap)

- Rettssak (ikke rettsak)

- Sinnssyk (ikke sinnsyk)

- Tidsskrift (ikke tidskrift)

- Tverrsnittsstudie (ikke tverrsnittstudie)

Uten fuge-s 


\section{Sjeflege eller sjefslege?}

To ord som kan volde besvær, er sjeflege og sjefslege (3). Sammensetninger med sjef-som forledd har dels ingen bindebokstav i fugen, dels -s-. Når betydningen er «den øverste, den høyeste», skal det ikke være noen bindebokstav. Det heter altså sjefarkitekt, sjefarkivar, sjefflyger, sjefforhandler, sjefideolog, sjefkokk, sjefredaktør, sjeftrener - og sjeflege (4.). I andre sammenhenger skal det imidlertid være sjefs-: sjefsegenskaper, sjefskontor, sjefsstilling, sjefsstol. Her er det rett og slett en genitivs-s (5). Forskjellen er kanskje enklest å se i ordparet sjefsekretær versus sjefssekretær. En sjefsekretær er sjef for sekretærene, mens en sjefssekretær er sjefens sekretær.

Men regelen om at sjef- brukes uten binde-s når ordet kan erstattes av «over-; den høyeste» er ikke egnet når det er snakk om leger (2). Stillingsbetegnelsen «over-lege» er ikke synonymt med «sjeflege», og det er nok heller ikke innlysende at sjeflegen er «den høyeste» eller «den beste» $(5,6)$.

En sjeflege er ifølge leksikonet en stillingsbenevnelse på sykehuslege som vanligvis er medisinsk-faglig rådgiver for direktøren (7.). Slike stillinger som sjeflege har i stor grad utgått eller fått andre betegnelser. Sjefslegen, derimot, er legen til sjefen ( $\underline{8})$. At sjefer holder seg med egne leger, er en sjeldenhet. I våre dager gjelder vel det stort sett statsoverhoder og andre fremstående personer, men slike leger omtales gjerne som livleger. Både sjeflege og sjefslege er altså stillingsbetegnelser som knapt er i bruk lenger.

\section{De beste kan feile}

Hva hadde skjedd ved Oslo universitetssykehus? På dobbeltsiden inne i avisen sto løsningen: «Dagsavisen kjenner til over ti tilfeller av leger i lederposisjoner ved OUS som har sagt opp som følge av fusjonstrøbbel» (9.). Det var altså tale om «leger i lederposisjoner». Men hvilket kort ord skulle Dagsavisen ha brukt? Andre medier som

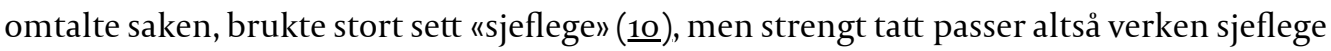
eller sjefslege her. Det er tale om «leger i lederposisjoner» - hva med «legeledere», «ledende leger» eller «toppleger»?

Fuge-s er et felt med få regler, og det kan gå galt for de beste. Da Legeforeningens nye generalsekretær Geir Riise ble portrettintervjuet i Tidsskriftet i 2009, sto det at han hadde vært «sjefslege» i både Statoil-konsernet og i NHO (11). Men det var sjeflege han hadde vært.

Jeg takker Petter Gjersvik for hjelp med manuskriptet.

\section{LITTERATUR}

1. Sjefsleger sier opp i protest. Dagsavisen 2.4.2012:1.

2. Fuge-s. Wikipedia. http://no.wikipedia.org/wiki/Fuge-s (4.4.2012).

3. Gundersen D. red. Bindebokstaver. I: Språkvett: skriveregler, grammatikk og språklige råd fra a til å. 2. utg. Oslo: Kunnskapsforlaget, 2002: 70.

4. Vinje F-E. Sammensatte substantiver. I: Moderne norsk: en veiledning i skriftlig framstilling: morfologiske og syntaktiske vanskeligheter. 5. utg. Bergen: Fagbokforlaget, 2002: 64. 
5. Stavem P, Gundersen D. Sjef fungerer som adjektiv i sjeflege, og følges derfor ikke av fuge-s. Tidsskr Nor Lægeforen 1992; 112: 2584-5.

6. Høie IM. Hematolog med språklig åre. Tidsskr Nor Lægeforen 2002; 122: 2934-5.

7. Sjeflege (Store medisinske leksikon). I: Store norske leksikon. http://snl.no/sjeflege (4.4.2012).

8. Ordliste S. Forfatterveiledningen. Tidsskrift for Den norske legeforening.

http://tidsskriftet.no/Innhold/Forfatterveiledningen/Spraak/Ordliste/S (4.4.2012).

9. Amundsen IH, Hvidsten I. Leger forlater gigantsykehuset. Dagsavisen 2.4.2012: 6-7. www.dagsavisen.no/samfunn/leger-forlater-gigantsykehuset/(4.4.2012).

10. Sjefleger ved Oslo universitetssykehus sier opp. www.aftenposten.no/nyheter/iriks/Sjefleger-vedOslo-universitetssykehus-sier-opp-6798025.html (4-4.2012).

11. Tveito M. Fra Posthuset til Legenes hus. Tidsskr Nor Legeforen 2009; 129:314-5.

Publisert: 26. juni 2012. Tidsskr Nor Legeforen. DOI:10.4045/tidsskr.12.0484

Mottatt 15.4. 2012, første revisjon innsendt 13.5. 2012, godkjent 24.5. 2012. Medisinsk redaktør Raida

$\emptyset$ degaard.

(C) Tidsskrift for Den norske legeforening 2023. Lastet ned fra tidsskriftet.no 26. april 2023. 